DOI: https://doi.org/10.32839/2304-5809/2021-11-99-70

удК 658.562 .64

Середа Д.Ю.

Харківський науково-дослідний експертно-криміналістичний центр Міністерства внутрішніх справ України

\title{
ПОНЯТТЯ ТОВАРОЗНАВЧОЇ ЕКСПЕРТИЗИ, ЇЇ ЦІЛІ ТА ЗАВДАННЯ
}

\begin{abstract}
Анотація. У статті розглянуто найактуальніші проблеми проведення та використання судових експертиз у кримінальному провадженні. Висвітлено наукові, правові та організаційно-тактичні засади підготовки та призначення судових експертиз, проведення експертних досліджень, оцінки експертного висновку та використання результатів експертизи під час досудового розслідування та судового розгляду. Уточнено поняття спеціальних знань, предмета, об'єктів, критерій диференціації судових експертиз, компетентності експерта. Розглянуто процесуальний порядок судової діяльності та запропоновано зміни та уточнення щодо кримінально-процесуального законодавства. Охарактеризовано поняття та напрями використання судово-товарознавчих експертиз у судовому провадженні, зокрема при кваліфікації злочинів та під час проведення тактичних дій. Удосконалено визначення судово-товарознавчої експертизи як процесуальної дії, сутність якої полягає у проведенні, за завданнями сторін судового провадження і суду, науково обгрунтованого дослідження судовим експертом-товарознавцем товарів, робіт і послуг, з метою встановлення їх товарних властивостей та іншої споживчої інформації у ході вирішення завдань судового провадження, iз застосуванням системи методів, яке оформляеться у вигляді висновку експерта. Розроблено наукові рекомендації щодо призначення судово-товарознавчої експертизи у судовому провадженні. Виокремлено критерії, яким повинен відповідати висновок судово-товарознавчої експертизи: законності, незалежності, об’єктивності і повноти дослідження.
\end{abstract}

Ключові слова: товарознавство, спеціаліст, експертиза, судово-товарознавча експертиза, спеціальні знання, форми використання спеціальних знань, консультативна допомога спеціаліста, спеціалісттоварознавець.

Sereda Daryna

Kharkov Scientific-Research Expert-Criminalistic Center of the Ministry of Internal Affairs of Ukraine

\section{THE CONCEPT OF COMMODITY EXAMINATION, ITS GOALS AND TASKS}

Summary. The article considers the most pressing problems of conducting and using forensic examinations in criminal proceedings. Scientific, legal and organizational-tactical principles of preparation and appointment of forensic examinations, conducting expert research, evaluation of expert opinion and use of examination results during pre-trial investigation and trial are covered. The notion of special knowledge, subject, objects, criterion of differentiation of forensic examinations, competence of the expert is specified. The procedural order of judicial activity is considered and changes and clarifications concerning the criminal procedure legislation are offered. The concept of tactics of forensic examinations is revealed, the expert situations arising in court proceedings are singled out, the corresponding actions of participants of court proceedings are specified. The concepts and directions of use of forensic commodity examinations in court proceedings, in particular at qualification of crimes and during carrying out of tactical actions are characterized. The subject of forensic commodity examination is determined, which is the actual data established in the process of studying the materials of court proceedings and the provided objects on the basis of special commodity knowledge and characterizes: goods, services, work; commodity properties; the actual condition of goods, the cost of goods and other consumer information. Improved definition of forensic examination as a procedural action, the essence of which is to conduct, on the instructions of the parties to the proceedings and the court, scientifically sound research forensic expert goods, works and services, in order to establish their product properties and other consumer information in the decision tasks of court proceedings, using a system of methods, which is drawn up in the form of an expert opinion. Scientific recommendations for the appointment of forensic examination in court proceedings, consisting of stages that include the following actions of the investigator: 1) determining the need for forensic examination; 2) the choice of the moment of appointment of such examination; 3) collection of necessary materials; 4) determination of the subject of forensic examination; 5) selection of an expert institution or expert; 6) drawing up a resolution on the appointment of forensic examination. The criteria that must be met by the conclusion of the forensic examination: legality, independence, objectivity and completeness of the study.

Keywords: commodity science, specialist, expertise, forensic commodity expertise, special knowledge, forms of use of special knowledge, consultative assistance of a specialist, commodity expert.

Постановка проблеми. Останні роки характеризуються докорінними змінами в соціально-економічному та політичному житті нашого суспільства. Процес відродження України як сильної та незалежної держави пов'язаний із подоланням значних труднощів. При розгляді та розслідуванні злочинів часто виникае необхідність застосування спеціальних знань у галузі товарознавства, у тому числі у формі товароз- навчої експертизи. Такі експертизи проводяться при виробництві неякісної продукції, контрабанді товарів, при розгляді судами цивільних справ, коли обставини справи зумовлюють необхідність дослідження споживчих властивостей продукції, товарів і сировини. Експертне дослідження таких об'ектів дозволяе визначити: їх різні параметри, властивості, різні обставини, пов'язані зі споживчими якостями; відповідність стандар- 
там, технічним умовам, зразкам; спосіб фральсифрікації цих об'ектів та способи запобігання різним правопорушенням.

Аналіз останніх досліджень і публікацій. Під час написання статті досліджено та використано роботи вчених у галузі фрілософрії та загальної теорії права, пов'язані з їі тематикою. Особливу увагу приділено роботам таких українських вчених, як Л.Ю. Арокер, О.М. Бандурка, В.П. Бахін, В.Д. Берназ, Т.В. Будько, Т.В. Варфоломе єва, А.Ф. Волобуєв, Л.М. Головченко, В.Г. Гончаренко, І.В. Гора, Г.Л. Грановський. У різний час вирішенню загальних завдань судових експертиз приділяли увагу зарубіжні правознавці: Т.В. Авер'янова, В.Д. Арсеньев, Р.С. Белкін, А.І. Вінберг, А.В. Дулов, Л.Г. Еджубов, О.О. Зайцева, О.М. Зінін, В.Я. Колдін, Ю.Г. Корухов, І.Ф. Крилов та ін. Ці вчені-правознавці зробили значний внесок у теорію судової експертизи, удосконалення законодавства та практики.

Виділення невирішених раніше частин загальної проблеми. Розгляд проблем проведення та використання судових експертиз є актуальним на сьогоднішній день. Реалізація положень Закону України «Про судову експертизу» дозволила значно підвищити загальний рівень судово-експертної діяльності як важливої складової правосуддя. В Законі міститься ряд положень що з часом не втратила актуальності, але й виявила багато проблем, вирішення яких потребує системного вдосконалення та уточнення нормативно-правової бази, що регулюе судову експертизу. Розуміння сутності судово-експертної діяльності, чітке розмежування самого поняття судово-товарознавчої експертизи серед інших видів експертиз є пріоритетним.

Формулювання цілей статті. Метою статті є дослідження сутності судової експертизи на базі аналізу українського законодавства та судової практики.

Виклад основного матеріалу дослідження. Належний рівень експертизи та правосуддя в Україні неможливий без розвитку теоретичних основ судової експертизи, розробки нових та вдосконалення існуючих методів експертного дослідження 3 метою впровадження результатів наукової роботи в експертну практику. Формування інституту судової експертизи відбувалося поступово, шляхом прийняття відповідних законодавчих актів та їх застосування на практиці. В результаті сорормована відповідна нормативно-правова база, яка регламентує організацію та проведення судових експертиз. Ця нормативно-правова база представлена Законом України «Про судову експертизу», а також низкою підзаконних актів.

Судова експертиза - це спосіб збору доказів, а саме тих фрактичних даних, які мають значення для правильного встановлення об'єктивних i суб'єктивних ознак кримінального правопорушення, тобто тих неочевидних фрактів, які можуть бути встановлені спеціалістом (спеціалістами) товарознавцем спеціальне вивчення відповідних об'єктів. На стадії досудового розслідування судово-товарознавча експертиза сприяе об'єктивності, повноті та всебічному пізнанню події та обставин кримінального правопорушення.

Так, у ст. 1 Закону України «Про судову експертизу» дається таке визначення судової екс- пертизи: «Судова експертиза - це дослідження на основі спеціальних знань у галузі науки, техніки, мистецтва, ремесла тощо об’єктів, явищ і процесів 3 метою надання висновку з питань, що $є$ або будуть предметом судового розгляду» [1, ст. 1].

Закон України про судову експертизу визначає правові, організаційні та фрінансові основи судової діяльності для забезпечення справедливості незалежної, компетентної та об'єктивної експертизи України, орієнтованої на максимальне використання науки і техніки, інших норм.

Звідси випливає, що будь-яка експертиза - це прикладне дослідження конкретного об'єкта, яке здійснюеться 3 метою досягнення не власне наукового, а прикладного знання.

Експертиза - процесуальний порядок збирання слідчим доказів за допомогою експерта, який самостійно на підставі постанови слідчого досліджуе необхідні предмети, зібрані у провадженні 3 метою встановлення нових фрактичних обставин 3 порушених слідчим питань.

Товарознавство - це застосування спеціальних знань не в будь-якій формі, а лише у формі дослідження. Відповідно, участь товарознавця для сприяння слідчому або суду у вчиненні процесуальної дії не можна назвати товарознавчою експертизою, результати такої спеціальної діяльності не мають доказової сили [4, с. 13].

Наше дослідження передбачає отримання нових фрактів, які раніше не були відомі слідчому чи суду і які іншим способом (наприклад, показаннями свідків) встановити неможливо. Іншими словами, товарознавча експертиза спрямована на виявлення фактичних даних, які можуть підтвердити (або спростувати) фракти, що мають юридичне значення.

Суть товарознавчої експертизи полягає в проведенні спеціального дослідження обізнаною особою (товарознавцем).

3 точки зору спеціальних знань у галузі товарознавства, проміжні результати, отримані на аналітичному та порівняльному етапах, $\epsilon$ новими фрактами, отриманими товарознавцем під час дослідження, аналіз яких потім дозволяє сфрормулювати остаточний висновок, який $є$ професійною оцінкою фрактів. Метою спеціального товарознавчого дослідження $є$ не просто констатувати нові фракти об'єктивної реальності, встановлені експертом, а профресійно їх оцінити.

Судова експертиза - це правова форма використання спеціальних товарознавчих знань у формі дослідження (правова фрорма спеціального дослідження) для досягнення певних правових цілей.

Основними відмітними ознаками судово-товарознавчої експертизи є:

a) оформлення висновку експерта;

б) мета: отримати нові знання про об'єкт дослідження та його професійну ощінку;

в) спеціальна процесуальна форма (призначення, проведення, отримання результатів);

г) предмет;

д) підставою виникнення процесуальних правовідносин щодо проведення судової експертизи $\epsilon$ постанова слідчого або ухвала суду;

е) інститут судової експертизи має самостійне значення в системі кримінально-процесуального права [4, с. 14]. 
Поняття судової експертизи включає дві необхідні складові: а) спеціальну (застосування спеціальних знань у формі дослідження); б) правові (дотримання процесуальної форми). Важливе значення для визначення судово-товарознавчої експертизи має іï мета, а саме: отримання судово-товарознавчих доказів (нових фактів, що мають значення для правильного вирішення обставин кримінального правопорушення).

Загалом експертиза складаеться 3 дослідження, перевірки, аналітичного дослідження, кількісної або якісної оцінки спеціалістом (експертом) або групою спеціалістів, експертною радою, спеціально уповноваженим державним органом (експертною організацією), органом виконавчої влади (у його межах чи компетенціï), підприємство, установа та організація всіх форм власності, а також об'єднання громадян певного питання, явища, процесу, предмета [6, с. 135].

На підставі викладеного можна виділити такі ознаки судової експертизи: а) застосування спеціальних товарознавчих знань у формі дослідження до певного об’екта та предмета; б) проведення дослідження спеціальним суб'єктом - експертомтоварознавцем за дорученням слідчого та суду, а також за клопотанням сторін кримінального провадження; в) дотримання процесуальної форми, в процесі оформлення результатів судовотоварознавчої експертизи; г) отримання нової інформації (фактичних даних) та оформлення результатів у вигляді висновку товарознавця, є самостійним видом судового доказу.

Розглянуті вище ознаки важливі для розуміння сутності судово-товарознавчої експертизи та визнання їі результатів судовими доказами. Проте стрижнем будь-якої експертизи, в тому числі й судової, е саме дослідження.

Як зазначає в своєму дослідженні Шевченко О.В., об’ектами дослідження при проведенні товарознавчої експертизи є різні вироби товарного походження, зразки (проби), а також матеріали кримінальних проваджень та цивільних справ, у яких викладені товарні характеристики досліджуваних об'ектів та інша інформація про обставини зміни споживчих властивостей $[7$, с. 366].

В своїй праці Т. Артюх зазначає, що об'єктами судово-товарознавчої експертизи е фактично існуючі або існуючі в минулому товари (продукція), зразки (зразки), а також документи (матеріали кримінальних і цивільних справ), які містять відомості про товар. характеристики досліджуваних об'єктів та різноманітні ситуації, пов'язані з операціями, пов'язаними з товаром (умови пакування, маркування, зберігання, транспортування, експлуатації, а також інші обставини, що мають значення для конкретного випадку). На думку цих авторів, до об’ектів такої експертизи не можна віднести предмети, які не мають ознак визначення їх товарної приналежності та здатності відноситись до певної товарної групи [4, с. 14].

Таким чином, можна зробити висновок, що об'єкт експертизи є специфрічним для кожного виду (виду) судової експертизи, тому його оригінальність $є$ важливою ознакою для розрізнення експертиз.

Поряд з безпосереднім вивченням предметів (продукції), маркування, зразків товарів під час судово-товарознавчої експертизи також працюють 3 документами, що відображають стан товару, різноманітні процеси, що відбуваються з ним при здійсненні товарних операцій (приймання, бракування, продажі, тощо). Такі документи дають додаткову інформацію про досліджуваний товар, а також можуть бути віднесені до об’ектів судово-товарознавчої експертизи.

Об’єктами судової експертизи є реально існуючі або існуючі в минулому а) продукція товарного походження (промислові та харчові групи); б) сировина, напівфабрикати, допоміжні матеріали; в) тару, упаковку комерційного призначення, у вигляді зразків (зразків), як нових, так і вживаних (уживаних); г) документи, що характеризують походження, вид, артикул, сорт, комплектність та інші показники товару; д) інші речові докази, матеріали кримінального провадження [4, с. 15].

Судово-експертну діяльність здійснюють державні спеціалізовані установи, їх регіональні відділення, комунальні спеціалізовані організації, а також позаштатні судові експерти та інші експерти (фахівці) суміжних галузей знань, в умовах, визначені законодавством України «Про судову експертизу» [1, ст. 7].

Судова експертиза проводиться на підставі ухвали відповідного суду чи органу досудового розслідування або за домовленістю з експертом чи експертним органом - якщо експертиза проводиться за клопотанням інших осіб.

Підставою для отримання висновку спещіаліста для з'ясування обставин судового правопорушення є запит посадової особи слідчого підрозділу Національної поліщії, органу безпеки, органу, що здійснюе нагляд за виконанням податкового законодавства, Державного бюро розслідувань, Національне антикорупційне бюро України досудове розслідування судових правопорушень [1, ст. 71].

Товарознавець, володіючи спеціальними товарознавчими знаннями, користуючись різними науковими методами і засобами, встановлюе об'єктивний факт або формулюе свої судження про фракт, що входить до предмета дослідження і який у конкретному випадку може збігатися 3 предметом експертизи. У свою чергу, цей факт, будучи одиничним явищем чи подією, пов'язаний з різними взаємозв'язками з іншими фактами, які встановлюються внаслідок дій слідчого чи судді (суду) у конкретному провадженні.

Результатом діяльності судового експерта е висновок, що, відповідно до вимог ч. 1 ст. 101 КПК України, е докладним описом проведених експертом досліджень і зроблених за їх результатами висновків, обтрунтованих відповідей на запитання, поставлені особою, яка залучила експерта, або слідчим суддею чи судом, що доручив проведення експертизи [5, с. 146].

Висновки 3 цього дослідження та перспективи. Враховуючи вищевикладене, можна зробити наступні висновки:

1. Дослідивши різні підходи до визначення понять предмета судової експертизи, приходить до висновку, що предметом такої експертизи є фактичні дані, які встановлюють у процесі вивчення матеріалів судового провадження та надані об’єкти, що характеризують: товари, послуги, роботу; товарні властивості; фоктичний стан товарів, вартість товарів та інша інформація для споживачів. 
3. Встановлено особливості мети судово-товарознавчої експертизи. Звернуто увагу на особливості збору даних, необхідних для призначення судовотоварознавчої експертизи, яка проводиться під час слідчих (розшукових) дій - оглядів, обшуків тощо. обгрунтовано первинні слідчі (розшукові) дії, зокрема огляд місця події та огляд документів.

5. Доведено, що призначення судово-товарознавчої експертизи, як етапу фрормування процесуального механізму інституту судової експертизи, детально врегульовано чинним законодавством.
6. Судова експертиза розглядається як процесуальна дія, суть якої полягає у проведенні за дорученням сторін кримінального провадження та суду науково обгрунтованого дослідження судовим експертом товарів, робіт і послуг з метою встановлення їх продукції.

7. Розглянуто теоретичні положення оцінки висновку судово-товарознавчої експертизи під час досудового розслідування та судового розгляду.

8. Акцентовано на використанні висновку судово-товарознавчої експертизи в процесі доказування.

\section{Список літератури:}

1. Про судову експертизу : Закон України № 1082-IX від 15.12.2020. URL: http://zakon3.rada.gov.ua/laws/ show/4038-12 (дата звернення: 27.11.2021).

2. Наказ Міністерства юстиції України «Про затвердження Інструкції про призначення та проведення судових експертиз та експертних досліджень та Науково-методичних рекомендацій з питань підготовки та призначення судових експертиз та експертних досліджень» від 08.10.98 № 53/5, зареестровано в Міністерстві юстиції України від 03.11.1998 // База даних «Законодавство України». URL: https://zakon.rada.gov.ua/laws/show/ z0705-98\#Text (дата звернення: 27.11.2021).

3. Тертишник В.М. Науково-практичний коментар до Судово-процесуального кодексу України. Київ : А.С.К., 2020. 1056 с. (Нормативні документи та коментарі).

4. Артюх T.М., Григоренко I.В. Теоретичні основи товарознавства : навчальний посібник. Київ : НУХТ, 2014.263 с.

5. Кандуї Н.П. Проблеми судових експертиз, що виникають під час реалізації нового КПК України 2012 року. Національний вісник Академї внутрішніх справ Украӥни. 2014. Випуск 4. С. 141-148. URL: http://elar.naiau.kiev.ua/bitstream/123456789/669/1/14.pdf (дата звернення: 01.02.2021).

6. Комаха В.О., Стрілець Г.О. Напрямки діяльності судово-експертних установ в системі Міністерства юстиції України. Збірник наукових праць / Ізмаїльський інститут водного транспорту. 2017. Випуск № 2. С. $143-148$. URL: https://dspace.nlu.edu.ua/handle/123456789/13914 (дата звернення: 01.02.2021).

7. Шевченко О.В. Поняття судово-товарознавчої експертизи. Актуальні питання техніко-криміналістичного забезпечення кримінальних проваджень : збірн. матер. кругл. столу (Київ, 21 листопада 2013 року). Київ : ННІПФЕКП НАВС, 2013. С. 365-370. URL: http://elar.naiau.kiev.ua/bitstream/123456789/669/1/14.pdf (дата звернення: 27.11.2021).

\section{References:}

1. Zakon Ukrayiny «Pro sudovu ekspertyzu» vid 04.06.2009 p. № 1445-VI [Law of Ukraine « On forensic examination» dated 15.12.2020 p. № № 1082-IX]. Database "Legislation of Ukraine". Available at: http://zakon3.rada.gov.ua/ laws/show/4038-12 (accessed 27 November 2021).

2. Nakaz Ministerstva yustytsiyi Ukrayiny «Pro zatverdzhennya Instruktsiyi pro pryznachennya ta provedennya sudovykh ekspertyz ta ekspertnykh doslidzhen' ta Naukovo-metodychnykh rekomendatsiy z pytan' pidhotovky ta pryznachennya sudovykh ekspertyz ta ekspertnykh doslidzhen'» vid 08.10.98 № 53/5, zareyestrovano v Ministerstvi yustytsiyi Ukrayiny vid 03.11.1998 [Order Ministry of Justice of Ukraine "On approval of the Instruction on appointment and conduct of forensic examinations and expert research and Scientific and methodological recommendations on the preparation and appointment of forensic examinations and expert research"» vid 08.10.98 № 53/5, registered in the Ministry of Justice of Ukraine from 03.11.1998]. Database "Legislation of Ukraine". Available at: https://zakon.rada.gov.ua/laws/show/z0705-98\#Text (accessed 27 November 2021).

3. Tertishnik V.M. (2020) Scientific and practical commentary to the Code of Judicial Procedure of Ukraine. Kyiv: A.C.K., 1056 p. (Normative documents and comments). (in Ukrainian)

4. Artykh T.M., Grigorenko I.V. (2014) Theoretical bases of commodity science: textbook. Kyiv: NUXT, 263 p. (in Ukrainian)

5. Kanufi N.P. (2014) Problemy sudovykh ekspertyz, shcho vynykayut' pid chas realizatsiyi novoho KPK Ukrayiny $2012 \mathrm{roku}$ [ Problems of forensic examinations that arise during the implementation of the new CPC of Ukraine in 2012]. National Bulletin of the Academy of Internal Affairs of Ukraine, vol. 4, pp. 141-148. Available at: https://dspace.nlu.edu.ua/handle/123456789/13914 (accessed 27 November 2021).

6. Komakha V.O., Strilec G.O. (2017) Napryamky diyal'nosti sudovo-ekspertnykh ustanov v systemi Ministerstva yustytsiyi Ukrayiny [Areas of activity of forensic institutions in the system of the Ministry of Justice of Ukraine]. Collection of scientific works, vol. 2, pp. 143-148. Available at: https://dspace.nlu.edu.ua/ handle/123456789/13914 (accessed 27 November 2021).

7. Shevchenko O.V. (2020) Ponyattya sudovo-tovaroznavchoyi ekspertyzy [Features of protection of plant variety rights in Ukraine]. Current issues of technical and forensic support of criminal proceedings: collection. mater. round. table (Ukraine, Kyiv, November 21, 2013), Kyiv: NNIPFEKP NAVS, pp. 365-370. Available at: http://dspace.pdaa.edu.ua:8080/bitstream/123456789/7768/1/conference\%20innovative\%20aspects_2020.pdf (accessed 27 November 2021). 